\title{
HUBUNGAN MINAT BACA DI PERPUSTKAAN DENGAN PRESTASI BELAJAR SISWA MATA PELAJARAN IPS DI SDN PEJAGAN 9 BANGKALAN
}

\author{
Dewi Septiani Mandasari \\ STKIP PGRI Bangkalan \\ dewiseptiani@stkippgri-bkl.ac.id
}

\begin{abstract}
:
This study aims to determine students' interest in reading in library. School library is an effective learning tool to improve student learning achievement, so that the school library is felt to be important, it is expected that the books in the library should not be just as a display. Therefore the school library needs to be managed and utilized to the maximum extent because the more reading in the library, the more insight into thinking and adding knowledge and finally there will be an increase in achievement in learning achievement. This research hypothesis "There is a Relationship between reading interest in library and student achievement in grade $V$ at SDN Pejagan 9 Bangkalan. The method used is the method of documentation, observation and questionnaire to support the research of the two variables. Then to find out the proposed hypothesis is accepted and rejected. The conclusion of this research is there is a relationship of interest in reading in the library with the learning achievement of fifth grade students at SDN Penjagan 9 Bangkalan this can be known from the $t$ value of 5.50 while according to the criteria of t table significant level of 5\% $=2.05$ and 152,76 thus the value of $t$ is greater than t table at the significant level of $5 \%$ and $1 \%$ so that the working hypothesis $(\mathrm{Ha})$ is accepted and $(\mathrm{Ho})$ is rejected
\end{abstract}

Keywords: Interest in Reading, Library, Learning Achievement

\begin{abstract}
Abstrak:
Penelitian ini bertujuan untuk mengetahui minat baca siswa di perpustkaan. Perpustkaan sekolah merupakan sarana belajar yang efektif untuk meningkatkan prestasi belajar siswa, sehingga perpustakaan sekolah dirasakan penting adanya, diharapkan buku buku yang ada di perpustakaan jangan hanya sebagai pajangan saja. Oleh sebab itu perpustkaan sekolah perlu dikelola dan dimanfaatkan semaksimal mungkin sebab semakin banyak membaca di perpustkaan maka akan semakin menambah wawasan berfikir dan menambah ilmu pengetahuan serta akhirnya akan nampak adanya peningkatan dalam prestasi dalam prestasi belajar. Hipotesis penilitian ini" Ada Hubungan minat baca perpustkaan dengan prestasi Belajar siswa kelas V di SDN Pejagan 9 Bangkalan. Metode yang digunakan adalah metode dokumentasi, observasi dan angket dalam menunjang penilitain kedua variabel. Maka untuk mengetahui hipotesis yang diajukan diterima dan ditolak. Kesimpulan dari penilitian ini adalah Ada hubungan minat baca di perpustakaan dengan prestasi belajar siswa kelas $\mathrm{V}$ di SDN pejagan 9 Bangkalan hal ini dapat diketahui dari nilai $t$ hitung sebesar 5,50 sedangkan menurut kriteria $t$ tabel taraf signifikan 5\% $=2,05$ dan 15 2,76 degan demikian nilai t hitung lebih besar dari t tabel pada taraf signifikan 5\% dan $1 \%$ sehingga hipotesis kerja (Ha) tersebut diterima dan (Ho) ditolak
\end{abstract}

Kata Kunci: Minat Baca, Perpustakaan, Prestasi Belajar 


\section{PENDAHULUAN}

Dalam Upaya meningkatkan kualitas pendidikan dilakukan pendekatanpendekatan tertentu. Ada tiga model parameter atau ukuran pendidikan yang berkualitas menurut beberapa pakar pendidikan, diantaranya pertama, kualitas pendidikan yang dilihat dari capaian tujuan pendidikan yang diukur melalui pencapaia atau perolehan output yang tinggi di bidang akademik (academic archievement).

Mengembangkan minat baca bagi masyarakat, khususnya anak-anak di sekolah dipengaruhi oleh beberapa factor, salah satu factor yang harus dipersiapkan adalah pedoman yang dijadikan sebagai acuan dalam melaksanakan kegiatan pengembangan minat baca. Meningkatnya minat baca dan kegemaran membaca merupakan salah satu tolak ukur untuk meningkatkan mutu pendidikan. oleh karena itu para kepala sekolah, guru, pengawas dan pustakawan bersama sama denga orang tua(wali murid) dan masyarakat di harapkan untuk ikut mendukung suksesnya pengembanagan minat baca dan kegemaran membaca siswa. Dalam kaitannya prestasi belajar tidak dapat terlepas dari factor penunjang lain, baik factor yang datangnya dari siswa itu sendiri seperti guru, sarana dan prasana yang menandai maupun lingkungannya.
Perpustakaan sekolah merupakan sarana belajar yang efektif untuk meningkatkan prestasi belajar siswa, sehingga perpustakaan sekolah dirasakan penting adanya. Diharapkan buku buku yang ada di perpustakaan jangan hanya sebagai pajangan saja namun harus merupakn sarana untuk memecahka persoalan, mengembangkan kreatifitas serta mematangkan kepribadiannya. Oleh karena itu perpustakaan perlu dikelola dan dimanfaatkan semaksimal mungkin sebab penulis yakin bahwa banyak membaca di perpustakaan maka akan semakin menambah wawasan peningkatakan dalam prestasi belajarnya.

\section{METODE PENELITIAN}

\section{Definisi Konsep}

1. Perpustakaan sekolah merupakan bagian internal dari lembaga pendidika tempat kumpulan buku bahan pustaka yang berupa buku maupun bukan buku, yang diatur menurut sistemn tertentu dan dipergunakan dalam ranga kegiatan belajar mengajar guru maupun murid

2. Prestasi belajar menurut W.J.SPoerwadarminto, (1994) adalah "Penilaian hasil usaha 
kegiatan belajar yang dinyatakan dalam perubahan tingkah laku, pengetahuan, pemahaman keterampilan atau kecakapan dan aspek-aspek lainnya yang ada dalam diri individu dalam waktu tertentu.

\section{Definisi Operasional Variabel}

Berdasarkan di atas, maka peneliti dapat menentukan variabel yaitu:

1. Variabel bebas atau Variabel $\mathrm{X}$ dalam penelitian ini adalah perpustakaan di SDN Pejagan 9 Bangkalan dengan indicator pemanfaatan oleh siswa, yang nilainya diambil berdasarkan nilai angket.

2. Variabel Terikat Y yaitu Prestasi Belajar siswa kelas V di SDN Pejagan 9 Bangkalan.

\section{Deskripsi Populasi}

"Popoulasi adalah keseluruhan subjek penelitian (Arikunto,2004) Apabila seseorang ingin meneliti semua elemen yang ada dalam wilayah penelitian, maka penelitiannya dinamakan penelitian populasi. Dalam melakukan penelitian dan pengumpulan agar diperoleh data yang dipertanggung jawabkan, maka menentukan deskripsi populasinya dengan mengadakan penelitian di Sekolah Dasar negeri 9 Kecamatan Bangkalan Kabupaten Bangkana Jadi Populasi adalah subyek yang menjadi
Ruang Lingkup Penelitian. Adapaun yang menjadi Subyek penelitian adalah Siswa Kelas V di Sekolah Dasar Negeri Pejagan Kabupaten Bangkalan.

\section{Metode Pengumpulan Data}

Mneurut Sutrisno

(2003) menyatakan bahwa" Antar metode pengumpulan data dengan masalah penelitian selalu berhubungan erat. Oleh karena itu pemakaian metode Pengumpuan data perlu memikirkan dan mempertimbangkan dengan teliti serta mengarah pada masalah penelitian"

\section{Metode Observasi}

Menurut Hadi (2002) adalaah Suatu cara untu mencari data dengan mengamati dan mencatat secara sistematis tentang fenomen fenomena yang diselidiki”. Observasi merupakan suatu cara untuk memperoleh data dengan cara mengamati melalui alat indera mata tentang kejadian-kejadian saat peristiwa yang sedang disedlidiki itu terjadi. Alasan Penggunaan metode observasi: (a) Data yang diperoleh kan lebih obyektif, (b) lebih mudah dalam mengecek obyek (c) Data data diperoleh secara langsung dari gejala serta peristiwa dari obyek yang diamati (d) Dapat mengetahui situasu yang guna dijakdikan sebagai masukan. 


\section{Metode Analisis Data}

Semua data yang terkumpul merupakan data yang masih mentah sehingga perlu diolah/dianalisa. Menurut Hadi (2006) adalah sebagai berikut:

1. Statistik memungkinkan catatan paling baik dalam hal penelitian

2. Statistik menyediakan cara meringkas data dalam bentuk yang lebih baik.

Jadi yang dimaksud analisis statistik adalah Pengumpulan data, menganilsa data yang berupa angka-angka dengan menggunakan tekhnik matematika yang hasilnya bisa membentuk tabel atau grafik.

Menurut Kamus Besar Bahasa Indonesia (2006) mengatakan Bahwa "Analisa data adalah Penelahaan dan pneguraian atas data hingga menghasilkan simpulan-simpulan. Metode Pengumpulan data masih merupakan data yang belum sempurna maka perlu adanya analisa dat. Karena data yang ditulis berupa angka serta dalam penelitian ini adalah kuantitatif. Dalam Penelitian ini mencari korelasi dari dua variabel, maka menggunakan rumus koefesien Korelasi Product Moment (Hadi, 2005). Pada penelitian ini jenis penelitiannya adalah penelitian deskriptif kuantitatif. Penelitian yang digunakan bertujuan untuk mengetahui hasil usaha kegiatan belajar yang dinyatakan dalam perubahan tingkah laku, pengetahuan, pemahaman keterampilan atau kecakapan dan aspek-aspek lainnya yang ada di daam diri individu dalam waktu tertentu.

Metode Pengumpulan Data metoe Pengumpulan data dengan masalah peneliti selalu berhubungan erat. Oleh karena itu pemakaian metode pengumpulan data perlu memikirkan dan mempertimbangkan dengan teliti serta mengarahkan pada masalah penelitian.

Metode observasi merupakan suatu cara memperoleh data dengan cara mengamati melalui indra mata tentang kejadian kejadian saat peristiwa yang sedang diselidiki itu terjadi. Penggunaan metode observasi

a. Data yang diperoleh akan lebih objektif

b. Lebih mudah dalam mengecek obyek

c. Data dapat diperoleh secara langsung dari gejala oeristiwa yang diamati

d. Dapat mengetahui medan yang diselidiki guna dijakdikan sebagai masukan yang berharga.

e. agar dapat memperoleh jawaban terhadap pertanyaan penelitian yang dipilih untuk mencapai tujuan penelitian, serta berperan sebagai alat dan pedoman untuk mencapai tujuan tersebut. Metode penelitan yang dilakukan dengan tujuan utama untuk memecahkan atau 
menjawab permasalahan yang sedang dihadapi pada situasi sekarang (Setiadi, 2013).

Peneliti mengumpulkan data yang masih mentah sehingga perlub diolah/ dianalisa. Sebelum menganilisa data terlebih dahulu penluis mengemukakakan definisi data. Jadi yang dimaksud analisa statistik adalah pengumpulan data, menganalisis data yang berupa angka angka dengan menggunakan tekhnik matematika yang hasilnya bisa membentuk tabel atau grafik.

Metode pengumpulan data masih merupakan data yang belum sempurna maka perlu adanya analisa data karena data yang ditulis berupa angka serta dalam penelitian ini adalah kuantitatif dalam penelitian ini mencari korelasi dari dua variabeli, maka menggunakan rumus koenfensien Korelasi Product Moment.

$$
=\frac{\sum X Y-\frac{\left(\sum X\right)\left(\sum X\right)}{N}}{\sqrt{\sum \sum X^{2}-\frac{\left(\sum X\right)^{2}}{N}\left\{\sum Y^{2}-\frac{\left(\sum Y\right)^{2}}{N}\right\}}}
$$

\section{Keterangan}

$\mathrm{N}=$ Jumlah siswa/sampel

$\sum \mathrm{X}=$ Jumlah Nilai Variabel bebas/ angket

$\sum \mathrm{Y}=$ Jumlah nilai variabel terikat/nilai raport

$\sum X Y=$ Jumlah Hasil kali variabel $\mathrm{x} d \mathrm{a}$ $\mathrm{y}$

$\sum \mathrm{X}^{2}=$ Jumlah kuadrat dari variabel bebas

$\sum \mathrm{Y}^{2}=$ Jumlah kuadrat dari variabel berikut

rxy $=$ Korelasi antara variabel $\mathrm{X}$ dan Variabel Y
III Uji Hipotesis

thit $=\sqrt{\frac{\left(r^{2}\right)(n-2)}{1-r^{2}}}$

1. Merumuskan penelitian menjadi hipotesis statistik

a. $\mathrm{Ha}=$ Ada Hubungan signifikan antar variabel bebas (x) dengan variabel terikat (y)

b. Ho = tidak ada hubungan yang signifikan antara variabel bebas(x) dan variabel terikat (y)

2. Menentukan taraf signifikan 5\% dan $1 \%$

3. Membandingkan antara $\mathrm{t}$ hitung dengan $t$ tabel

a. Jika $\mathrm{t}$ hitung lebih besar dari $\mathrm{t}$ tabel, maka Ha diterima dan Ho ditolak artinya ada hubungan yang signifikan antara variabel bebas dengan variabel terikat

b. Jika $\mathrm{t}$ hitung lebih kecil dari $\mathrm{t}$ tabel, maka Ha ditolak dan Ho diterima artinya tidak ada hubungan yang signifikan antara variabel bebas dengan variabel terikat.

\section{KESIMPULAN}

Berdasarkan hasil analisa data dan interprestasi di atas dapat menarik kesimpula yang merupakan hasil dari suatu penelitian yaitu ada Hubungan minat baca di perpustakaaan dengan prestasi belajar siswa Kelas V di SDN Pejagan 9 Bangkalan. Hal ini diketahui dari nilai $\mathrm{t}$ hitung sebesar 5,50 sedangkan menurut kriteria $t$ tabel taraf signifikan $5 \%=2,05$ dan 15 , sehingga hiotesa krja (Ha) tersebut diterima dan Hipotesa nihil (Ho) ditolak. 
Terwujudnya prestasi belajar yang maksimal dari siswa tak akan lepas dari faktor-faktor yang terkait erat dengan dunia pendidikan, utamanya faktor lingkungan dan keluarga. Oleh karena itu orang tualah yang mengenalkan pertama kali dunia sekitar sebelu ia menerima nilai nilai dari pendidikan lain dan luar keluarga. Dengan demikian sebgaai masukan dan sran bagi semua orang tua siswa agar mendukung tercapainnya prestsi belajar:

1. Pada guru menangani perpustakaan hendaknya mengawasi secara langsung jalannya pelayanan di perpustkaan sekolah dengan memberikan motivasi kepada siswa untuk mencapai cita-cita

2. Guru pustakawan dan guru lainnya harus memberikan teladan kepada siswa untuk memanfaatkan perpustkaan sekolah semaksimal mungkin sehingga siswa akan menirunya

3. Hendaknya guru dapat membina, memupuk dan mengembangkan minat baca di perpustakaan

4. Sebaiknya para guru dan pustakawan dapat menyediakan fasilitas yang diperlukan oleh siswa untuk keperluan sekolah yang juga merupakan faktor penunjang dalam meningkatkan prestasi belajar siswa.

5. Sekolah harus menjalin hubungan kerja yang baik dengan komite sekolah atau masyarakat khususnya dalam rangka pengadaan media dan gedung perpustakaan sebagai gudang ilmu pengetahuan.

\section{DAFTAR PUSTKA}

Amir, I.K. (2011). Pengantar ilmu Penididikan, Usaha Nasional. Malang Departemen P dan K RI (2012), Kamus Besar Bahasa Indonesia,jakarta.

Kartono Kartini,K. (2013). Perananan Keluarga Memandu Anak, Rajawali Pers, Jakarta

Rostiawati Yustiana, R. (2012) Dasar Dasar Ilmu Pendiidkan, PT. Ramedia Pustaka Utama, Jakarta.

Suharsimi,A. (2013).Prosedur Penelitian suatu Pendekatan Praktek, Jakarta, rineka Cipta

Sutrisno, H. (1993).Statistik 2, Yayasan Penerbit Fakultas Psikologi UGM, Yogyakarta

Sutrisno, Joko Subandowo, Msuyono, (2014) Buku Pedoman Penelitian, IKIP Surabaya

Suwarno. (2012) Pengantar Umum Pendidikan ,Rineka Cipa Jakarta.

Suwono, (2013). Pedidikan Dasar Semesta, Rineka Cipta,Jakarta 